\title{
PELATIHAN PENYUSUNAN KONTEN PEMBELAJARAN DARING BAGI PETUGAS TAMAN BACA MASYARAKAT SURABAYA DI MASA PANDEMI COVID-19
}

\section{TRAINING FOR THE DEVELOPMENT ONLINE LEARNING CONTENT FOR TAMAN BACA MASYARAKAT SURABAYA OFFICERS IN PANDEMIC TIME COVID-19}

\author{
Kukuh Yudha Karnanta ${ }^{1}$, Laily Hamida ${ }^{2}$ \\ 1,2, Departemen Bahasa dan Sastra Inggris, Fakultas Ilmu Budaya, Universitas Airlangga \\ e-mail: kukuhyudha.karnanta@fib.unair.ac.id
}

\begin{abstract}
Since 2014, Surabaya has been declared as a 'literacy city' by the government. 1428 public library has been established while 595 librarians have been employed to conduct public literacy education. However, during pandemic Covid-19, the literacy program faces many problems and has been totally shut down. Based on observation, the problem comes from the lack of technology as a tool and media as well as insufficient skill to perpetrate a literacy program through an integrated learning management system. Therefore, English Department carried out a community service program entitled Arranging E-learning for librarians in Dinas Perpustakaan dan Kearsipan Kota Surabaya. This community service aims to initiate a literacy education content through e-learning and conduct training of the trainer to the librarians.
\end{abstract}

Keywords: e-learning, literacy, public library, Surabaya

abstrak

Surabaya dideklarasikan sebagai kota literasi sejak 2014. Hal tersebut diwujudkan dengan didirikannya 1428 Taman Baca Masyarakat (TBM) di Surabaya mencapai 1428 TBM, dengan tenaga pendamping TBM mencapai 595 orang. Namun di masa pandemi Covid19 ini aktivitas pendidikan literasi di Surabaya berjalan tidak maksimal, untuk tidak dikatakan berhenti sama sekali. Berdasarkan hasil observasi dan wawancara yang telah dilakukan oleh peneliti, belum adanya sistem media pembelajaran daring serta belum terampilnya petugas Taman Baca Masyarakat dalam memanfaatkan teknologi informasi sebagai ide penyusunan pembelajaran daring merupakan akar permasalahan. Oleh karena itu, kegiatan pengabdian pada masyarakat ini adalah untuk, pertama, menginisiasi penyusunan konten pendidikan literasi berbasis pembelajaran daring (elearning). Kedua, menyelenggarakan program pelatihan penggunaan media pembelajaran daring untuk tenaga petugas Taman Baca Masyarakat di Surabaya.

Kata kunci: literasi, pembelajaran daring, taman baca masyarakat, Surabaya

\section{PENDAHULUAN}

Sejak terbitnya Surat Edaran Nomor 36962/MPK.A/HK/2020 perihal pembelajaran daring dalam rangka pencegahan virus Covid-19 oleh Kementerian Pendidikan dan Kebudayaan, serta perpanjangan masa tanggap darurat Corona hingga setidaknya 29 Mei oleh Badan Nasional Penanggulangan Bencana, praktis pelayanan pendidikan literasi di Surabaya nyaris terhenti sama sekali. Padahal, Surabaya sudah mencanangkan dirinya sebagai Kota Literasi. Lima tahun sudah Surabaya Kota Literasi (SKL) dicanangkan tepatnya pada 2 Mei 2014 oleh Walikota Tri Rismaharini. Literasi memang penting bukan hanya karena beririsan langsung dengan angka indeks pembangunan manusia (IPM), melainkan juga menjadi salah satu variabel dari Indeks Pembangunan Kebudayaan (IPK) yang segera diluncurkan pada Oktober 2019 oleh Kemendikbud. Artinya, diskusi mengenai gerakan literasi di Surabaya mustahil 
dilepaskan dari isu-isu kebudayaan sehingga diperlukan adanya rumusan model dan strategi pelaksanaan yang utuh dan berkesinambungan.

Sejak awal dicanangkan, SKL secara konkret terwujud melalui 1438 titik baca, dengan 463 di antaranya berbentuk Taman Baca Masyarakat (TBM) yang tersebar di Balai RT/RW, taman, rumah sakit, dan rumah susun. Tenaga pendamping TBM yang bertugas melayani pengunjung pun lebih dari jumlah TBM yang ada. Terbaru, Dinas Perpustakaan dan Kearsipan yang mengeksekusi program tersebut meluncurkan e-perpustakaan berbasis sistem Digital Integrated Library System (DILS) yang bisa diakses di dispusip.surabaya.go.id. Gerakan sekaligus gebrakan tersebut sungguh sangat layak diapresiasi. Namun, lima tahun berjalan, program SKL secara umum agaknya masih menyisakan beberapa hal yang perlu dicermati untuk bisa disempurnakan ke depannya.

Penulis telah menyampaikan beberapa pandangan serta usulan program kepada Dispusip dalam Forum Perangkat Daerah yang diselenggarakan pada 28 Februari 2020. Beberapa pandangan tersebut menjadi dasar ide untuk penyusunan proposal pengabdian pada masyarakat ini. Pertama, di sepanjang 2014-2018 belum ada model aktivitas pendidikan literasi berbasis daring. Aktivitas pendidikan literasi yang selama ini terjadi masih bersifat tradisional dengan metode tatap muka antara petugas TBM dengan warga yang didominasi anak sekolah dasar hingga menengah. Metode ini kerap menemui hambatan saat, misalnya, dikarenakan cuaca, petugas berhalangan/tidak masuk, dan terutama saat masa tanggap darurat corona berlangsung. Proses belajar dan hasilnya pun tidak terdokumentasi dengan baik karena masih mengandalkan media-media pembelajaran seperti kertas, buku, yang seluruhnya bersifat fisik. Sedangkan menurut Wichadee (2018) Sesuai dengan kebutuhan pelajar abad ke-21 dan mencocokkan preferensi gaya belajar mereka, blended learning adalah tawaran inovatif yang membuat proses pembelajaran lebih efektif dan nyaman.

Kedua, perlunya pemanfaatan teknologi informasi sebagai media pembelajaran penulisan kreatif. Dengan sistem daring, aktivitas pendidikan literasi bisa berjalan lebih fleksibel, terarah, dan terdokumentasi dengan baik. Selain itu, karakter teknologi informasi memungkinkan adanya pengayaan konten pembelajaran sehingga tampak lebih menarik dan sesuai dengan perkembangan zaman. Senada dengan panduan GLN, yang mengharuskan masyarakat Indonesia wajib menguasai literasi digital demi menyukseskan pembangunan Indonesia di abad ke-21 (Kemendikbud, 2017).

Ketiga, program-program literasi seperti Kelas Literasi Menulis, Safari Literasi, Kampung Sains, dan lainnya belum sepenuhnya menyasar seluruh elemen masyarakat, melainkan lebih banyak pada anak-anak berusia sekolah khususnya SD dan SMP. Pilihan membidik siswa sekolah tentu bukan hal yang keliru, namun ke depan Pemkot perlu menjangkau publik luas. Fenomena masih maraknya berita hoaks, ujaran kebencian, serta sentimen berbasis agama dan etnis bisa diredam bila seseorang memiliki daya literasi yang kuat.

Dalam hal ini, daya literasi bukan sekadar tentang kemampuan membaca dan menulis, melainkan juga praktik 'menafsir'. Yakni, memilih dan memilah informasi (seleksi), memahami (rekognisi), membandingkan (komparasi), merasakan (refleksi), dan menciptakan-kembali (kreasi). Richard Kern (2000) memberi definisi yang lengkap tentang literasi, yakni "The use of socially and historically and culturally situated practices of creating and interpreting meaning through texts. It entails at least a tacit awareness of the relationships between textual conventions and their context of use and, ideally, the ability to reflect critically on those relationships." Dari definisi tersebut dapat diambil pokok pikiran bahwa pertama, pendidikan literasi sesungguhnya suatu praktik multidisipilin ilmu yang di 
dalamnya memuat antara lain sejarah, budaya, dan sosial. Daya literasi perlu dilatih sejak dini, memang, dan hal tersebut juga perlu dimiliki oleh seluruh elemen warga.

Berdasarkan paparan di atas, dapat dirumuskan permasalahan yang dihadapi oleh Dinas Perpustakaan dan Kearsipan Kota Surabaya adalah belum adanya media pembelajaran daring di Dinas Perpustakaan dan Kearsipan dalam hal penyelenggaraan pendidikan literasi khususnya tentang Penulisan Kreatif; serta belum terampilnya tenaga petugas Taman Baca Masyarakat dalam memanfaatkan media pembelajaran daring dalam hal penyelenggaraan pendidikan literasi

\section{METODE PENGABDIAN MASYARAKAT}

Metode yang digunakan dalam program pengabdian ini adalah mixed method. Tahap pertama diawali dengan melakukan survei dan wawancara kepada 471 Petugas TBM Kota Surabaya. Terdapat dua capaian utama untuk mengkaji terkait aspek konstruksi bukti, yaitu: peserta mampu menyusun materi penulisan kreatif dan terampil menggunakan teknologi informasi sebagai sarana pembelajaran penulisan kreatif. Dari hasil uji coba, para Petugas TBM diharapkan dapat mengimplementasikan pembelajaran literasi dalam LMS melalui sarana e-learning.

\section{HASIL DAN PEMBAHASAN}

Langkah strategis yang dilakukan penelitian adalah melakukan observasi terhadap keadaan TBM Kota Surabaya melalui survei yang dilakukan kepada para 481 Petugas TBM. Hasil menunjukkan bahwa sebanyak $80 \%$ menjawab terjadi penurunan intensitas kegiatan dan kunjungan di TBM Kota Surabaya, hal ini berkaitan dengan pemberlakuan pembelajaran jarak jauh dan PSSB. Terdapat usaha memberikan pembelajaran daring kepada para pengunjung yang dilakukan oleh para Petugas TBM, data menunjukkan sebanyak 92,4\% Petugas TBM menggunakan platform percakapan virtual seperti WhatsApp Group dan Line Group.

Metode pembelajaran yang digunakan belum efektif dalam memberikan pembelajaran literasi kepada para pengunjung TBM Kota Surabaya. Kendala utamanya adalah infrastruktur yang mengakomodasi penyelenggaraan pembelajaran daring, pertama, sebanyak $61.1 \%$ menyebutkan kendala koneksi internet masih menjadi permasalahan yang terbesar. Kedua, sebanyak $55.1 \%$ menyebutkan belum ada kesiapan untuk melakukan pendidikan literasi secara daring dari kedua belah pihak, baik pengunjung maupun Petugas TBM. Ketiga, sebanyak 106 atau 23.6\% Petugas TBM belum memahami cara menggunakan fitur-fitur pembelajaran interaktif secara daring, hal tersebut juga berimbas pada hasil $15.8 \%$ responden yang menjawab suasana belajar daring melalui platform WhatsApp atau Line menjadi kurang akrab. 


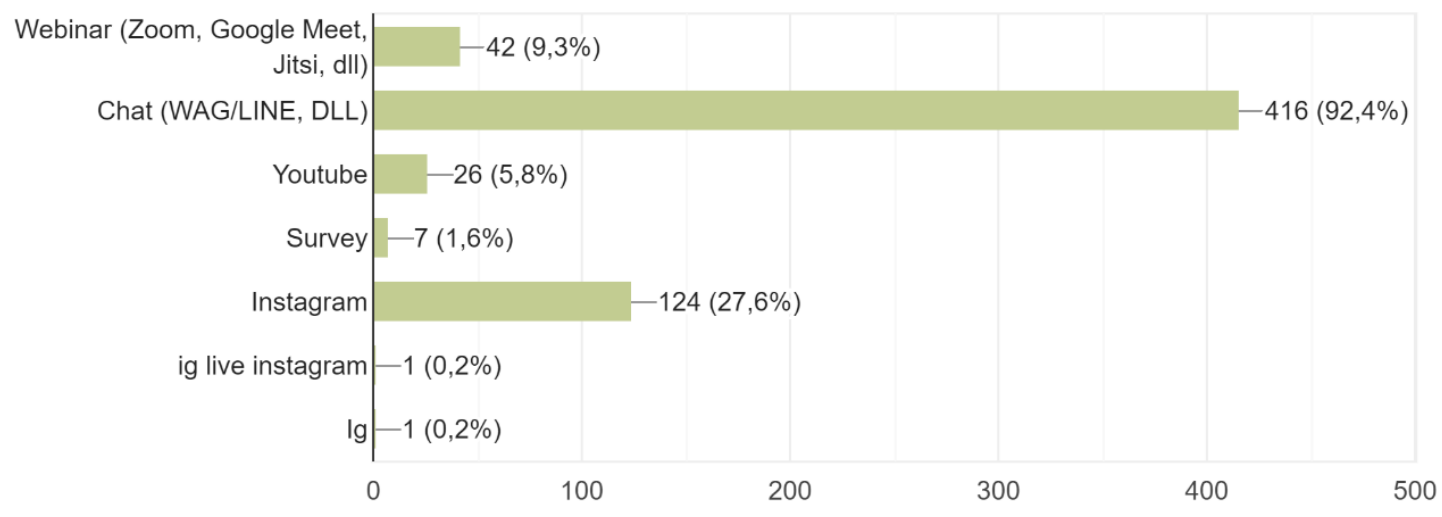

Gambar 1. Preferensi Media Petugas TBM

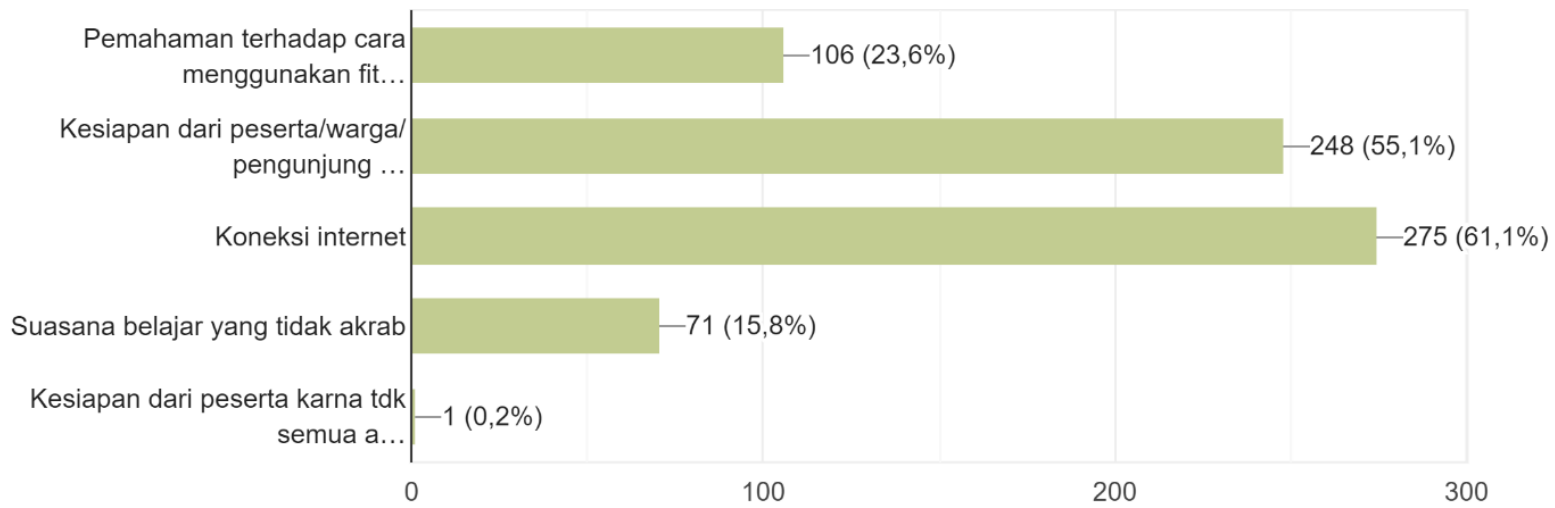

Gambar 2: Kendala Petugas TBM Kota Surabaya Dalam Melakukan Pelayanan Pendidikan Literasi secara Daring

Bradford S. Bell dan Jessica E. Federma (2013) dalam artikel E-Learning in Postsecondary Education menjelaskan e-learning bukan suatu metode belajar yang lebih baik atau lebih buruk dibanding dengan metode belajar konvensional. Keterampilan pedagogis, dalam arti kemampuan mengajar dari tutor/guru adalah yang paling utama. Keterampilan tutor/guru dalam memanfaatkan fitur-fitur elearning juga sangat penting. Bell dan Federman menyebut terdapat empat prinsip utama yang mutlak perlu yakni content, immersion, interactivity, dan communication. Ide konten pembelajaran daring bisa berupa film, iklan, novel, video klip, dan lain-lain sehingga konten bisa lebih variatif dan menarik. Kontenkonten tersebut membuat kondisi bisa 'serealistis' mungkin seakan siswa sedang berada di 'sekolah'.

Dengan kondisi serupa itu, program pengabdian ini menyusun suatu konten pembelajaran daring yang berprinsip pada content, immersion, interactivity, dan communication, dengan fokus pada penulisan kreatif. Dalam hal ini, penulisan kreatif adalah praktik penulisan yang didasarkan pada pengalaman dan interpretasi penulisnya terhadap kehidupan sehari-hari yang ditulis dengan format tertentu. Menulis menjadi sesuatu yang krusial dalam proses belajar seseorang karena dalam aktivitas menulis, seluruh kemampuan kognitif meliputi penganalogian, penghayatan, pendalaman, penjelasan, dan penciptaan kembali terjalin sebagai suatu kesatuan sebagaimana pada tabel 1 berikut ini: 
Tabel 1. Silabus Pelatihan

1. DESKRIPSI

2. CAPAIAN

PROGRAM

3. SUB CAPAIAN PROGRAM

4. LUARAN

PROGRAM

5. INDIKATOR KEBERHASILAN

6. FASILITATOR
Pelatihan ini bertujuan menginisiasi penyusunan konten layanan pendidikan literasi secara daring (elearning) dengan fokus pada materi penulisan kreatif. Melalui pelatihan ini, petugas Taman Baca Masyarakat di lingkungan Dinas Perpustakaan dan Kearsipan Kota Surabaya akan mendapatkan wawasan terkait penulisan kreatif serta penggunaan media teknologi informasi berbasis Moodle sebagai sarananya. Selanjutnya, diharapkan petugas TBM bisa menyusun konten secara mandiri dan menerapkannya dalam pelayanan rutin pendidikan/gerakan literasi di Surabaya.

1) Peserta mampu menyusun materi penulisan kreatif sebagai bagian dari agenda Gerakan Literasi Nasional

2) Peserta terampil menggunakan teknologi informasi sebagai sarana pembelajaran penulisan kreatif

1) Peserta terampil menggunakan Bahasa Indonesia ragam baku dalam memberi pelayanan pendidikan literasi

2) Peserta mampu mengidentifikasi struktur artikel resensi, opini, dan cerpen

3) Peserta mampu menyusun draf artikel resensi atau resensi

4) Peserta mampu menyusun perencanaan program pelatihan menulis secara mandiri untuk TBMnya.

5) Peserta mampu menyiapkan materi-materi terkait program pelatihan menulis yang akan diselenggarakan di TBM masing-masing.

1) Draf perencanaan program pelatihan menulis (lesson plan) di TBM

2) Draf resensi, berita, dan opini

1) Kesesuaian antara materi penulisan kreatif yang disusun oleh peserta dengan target audiens (warga binaan)

2) Kemampuan menggunakan teknologi informasi khususnya Moodle untuk penyelenggaraan layanan pendidikan literasi

1) Kukuh Yudha Karnanta S.S., M.A

2) Dr. Layli Hamidah S.S., M.Hum.

3) Tim

Tim menyusun strategi pelatihan dengan bekerja sama dengan Pusat Inovasi Pembelajaran dan Sertifikasi (PIPS) Universitas Airlangga untuk meminjam akun Massive Online Open Courses (MOOC) yang berbasis Moodle. Hal tersebut dikarenakan Dispusip belum memiliki 
learning management system. Program pelatihan tersebut diselenggarakan sebanyak enam kali pertemuan dengan rincian sebagai berikut.

Tabel 2. Pelaksanaan Program Pelatihan

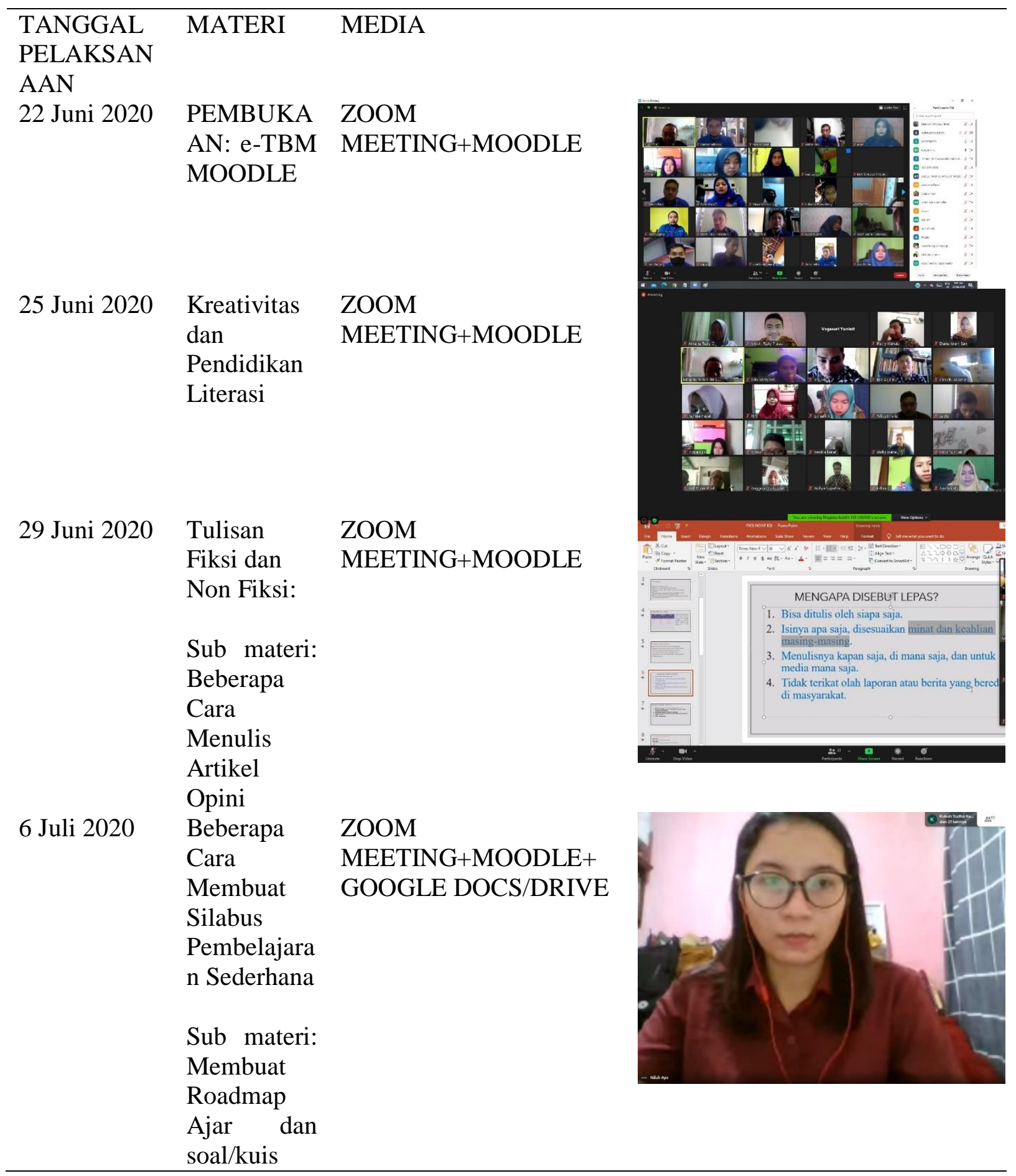




\begin{abstract}
9 Juli 2020
Pemanfaata

n fitur-fitur

di Moodle

ZOOM

MEETING+MOODLE+

(KUIS, GOOGLE DOCS/DRIVE

LABEL,

LINK,

ASSIGNM

ENT,

FORUM,

CHAT

DLL)

Sub materi:

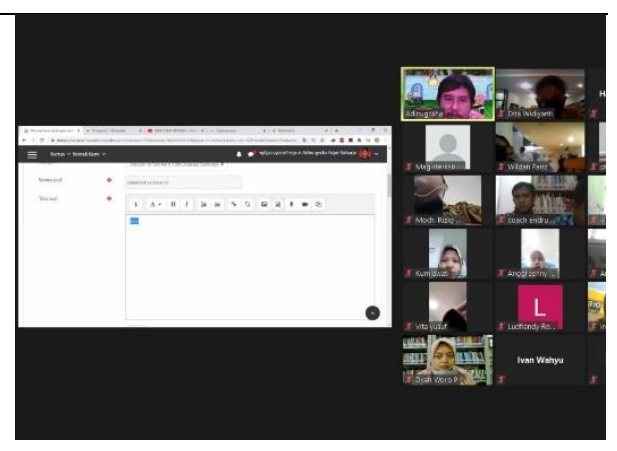

13 Juli 2020

Presentasi

ZOOM

dan

Simulasi

Kelompok

MEETING+MOODLE+ GOOGLE DOCS/DRIVE

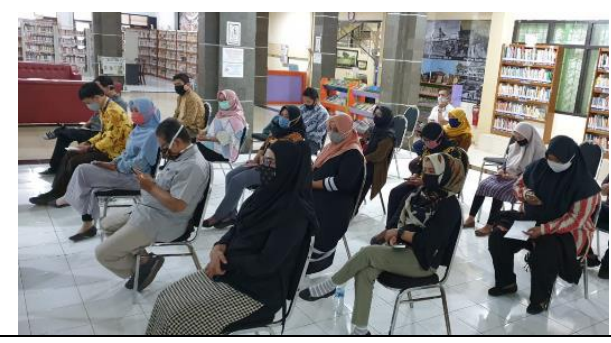

Kegiatan tersebut relatif lancar meskipun terdapat beberapa kendala seperti petugas TBM yang menjadi subjek-partisipan uji coba produk memang mengikuti pelatihan secara rutin, namun belum sepenuhnya menunjukkan performa yang maksimal dikarenakan di saat yang sama mereka harus mengerjakan tugas-tugas yang diberikan oleh Dinas Perpustakaan dan Kearsipan. Permasalahan klasik namun selalu terulang yakni stabilitas koneksi internet yang berbeda-beda yang dimiliki petugas juga terkadang menjadi hambatan saat synchronous. Meskipun demikian, kegiatan tersebut memberikan pengetahuan baru bagi para Petugas TBM dalam memberikan pembelajaran literasi secara daring, dibuktikan dengan tanggapan sebanyak 97,3\% dari Petugas TBM terhadap pembelajaran synchronous menjawab materi yang diberikan sudah jelas dan mudah dimengerti. Begitu pula dengan pembelajaran asynchronous yang sifatnya lebih cenderung pada praktik mengaplikasikan model pembelajaran literasi, sebanyak 97,3\% merespons positif terhadap fasilitator yang memandu proses praktik mengimplementasikan model pembelajaran literasi secara daring melalui Moodle.
\end{abstract}


Apakah cara tutor/pemateri memberikan penjelasan jelas dan mudah dimengerti? 37 tanggapan

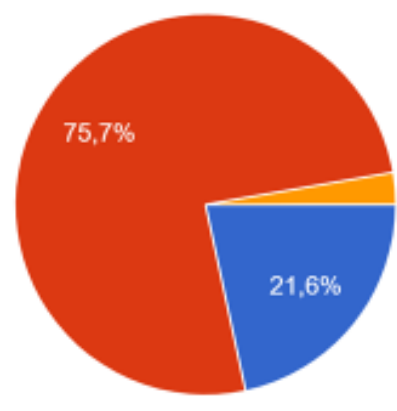

Sangat jelas dan sangat mudah dimengerti

Jelas dan mudah dimengerti

Tidak Jelas dan tidak mudah dimengerti

Apakah tutor/pemateri memandu Anda dalam proses mengunggah materi di Moodle? 37 tanggapan

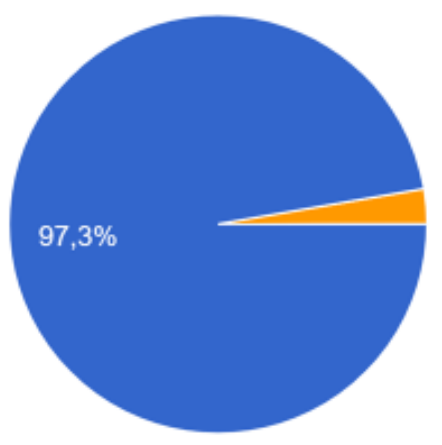

Ya, tutor memandu proses mengunggah

Tidak, tutor tidak memandu proses mengunggah

memandu tetapi terlalu cepat agak kesulitan untuk mengikuti kalau bersamaan dengan mengikuti zoom

Gambar 3. Respons Peserta terhadap Kegiatan Pelatihan

Proses pembelajaran tidak berhenti pada proses eksplorasi dan interpretasi, namun juga memperhatikan proses sintesis dengan cara mendampingi para petugas TBM dalam pembuatan platform pembelajaran literasi secara daring. Fasilitator menyediakan akun Massive Online Open Courses (MOOC) yang berbasis Moodle sebagai platform simulasi sebelum disajikan dalam platform LMS dari Dispusip dan membuka pembelajaran literasi kepada pengunjung virtual TBM Kota Surabaya (lihat figur 4). Target capaian yang harus dipenuhi oleh para petugas TBM adalah mengubah materi-materi pembelajaran literasi konvensional menjadi digital atau dapat diakses secara daring, serta pembelajaran literasi interaktif yang accessible dan inclusive bagi masyarakat Kota Surabaya. Setelah proses simulasi melalui akun MOOC telah rampung, pada bulan September 2020, Dispusip resmi meluncurkan https://tamankalimas.surabaya.go.id/ sebagai LMS berbasis Moodle yang terbuka bagi publik. Kursus yang disediakan adalah kelas mendongeng, penulisan, prakarya, multimedia, numerisasi, dan musik.

\section{SIMPULAN}

Paparan tersebut di atas menunjukkan bahwa pengabdian pada masyarakat ini berhasil memberikan dampak praksis yang signifikan. Indikatornya adalah, pertama, layanan pendidikan literasi Pemkot yang sebelumnya belum secara daring, kini menjadi sepenuhnya 
daring; kedua, silabus pembelajaran yang dipakai Pemkot adalah hasil dari model yang dibuat oleh tim yang juga mengakomodasi kepentingan dan keinginan mitra pengabdian. Pada akhirnya dapat disimpulkan bahwa pendidikan literasi melalui teknologi informasi menggunakan sarana Moodle dapat menjadi salah satu solusi untuk permasalahan aksesibilitas dan inklusivitas TBM Kota Surabaya saat masa darurat Covid-19; dan diharapkan dapat berkesinambungan dengan tujuan GLN dalam meningkatkan kompetensi yang meliputi kemampuan berpikir kritis/memecahkan masalah, kreativitas, komunikasi, dan kolaborasi.

\section{SARAN}

Beberapa saran yang dapat direkomendasikan untuk Dispusip Kota Surabaya adalah Peningkatan Infrastruktur, Penyediaan Moodle yang terintegrasi dengan website Dispusip sebagai sarana utama dalam mewujudkan pendidikan literasi yang accessible dan inclusive berbasis teknologi informasi bagi masyarakat Surabaya, diiringi dengan akses E-Learning, EArsip, ruang penyimpanan daring, serta pengadaan akses internet bagi Petugas TBM Kota Surabaya. Peningkatan Sumber Daya Manusia, Pemetaan kembali petugas TBM berdasarkan latar belakang keilmuan dan minat; serta pelatihan berjenjang, berkelanjutan, dan bersertifikat perihal enam jenis literasi dasar (Literasi baca-tulis, numerisasi, sains, finansial, digital, dan budaya dan kewarganegaraan) sesuai amanat GLN.

\section{UCAPAN TERIMA KASIH}

Terima kasih kepada Lembaga Pengabdian dan Pengembangan Masyarakat Universitas Airlangga yang telah mendanai kegiatan ini. Juga kepada Pusat Inovasi Pembelajaran dan Sertifikasi (PIPS) Universitas Airlangga yang turut terselenggaranya kegiatan ini. Kegiatan ini mustahil berjalan lancar tanpa kesediaan jajaran pimpinan Dinas Perpustakaan dan Kearsipan Kota Surabaya.

\section{DAFTAR PUSTAKA}

Kern, Richard. 2000. Literacy and Language Teaching. New York: Oxford University Press

Bell, B. S., \& Federman, J. E. (2013). E-learning in postsecondary education. The Future of

Children, 23(1), 165-185. Retrieved [insert date], from Cornell University, School of Industrial and Labor Relations site: http://digitalcommons.ilr.cornell.edu/articles/928

Wichadee, S. 2018. "Significant predictors for effectiveness of blended learning in a language

Course". JALT CALL 14, No.1: 25-42

Kemendikbud, TIM GLN. 2017. Panduan Gerakan Literasi Nasional. Jakarta: Kementerian Pendidikan dan Kebudayaan . 